Case Report

\title{
Use of KRD-PACE as Salvage Therapy in Aggressive, Relapsed/ Bortezomib-Refractory Extramedullary Multiple Myeloma: A Report of Two Cases and Literature Review
}

\author{
Ricardo D. Parrondo $\left(\mathbb{D},{ }^{1}\right.$ Vivek Roy $\mathbb{D}^{1},{ }^{1}$ Taimur Sher $\mathbb{D}^{1},{ }^{1}$ Victoria Alegria, \\ Asher A. Chanan-Khan, ${ }^{1,2}$ and Sikander Ailawadhi $\mathbb{D}^{1}$ \\ ${ }^{1}$ Department of Hematology-Oncology, Mayo Clinic Florida, Jacksonville, FL, USA \\ ${ }^{2}$ Department of Hematology-Oncology, St. Vincent's Riverside, Jacksonville, FL, USA \\ Correspondence should be addressed to Sikander Ailawadhi; ailawadhi.sikander@mayo.edu
}

Received 6 January 2020; Accepted 30 January 2020; Published 18 February 2020

Academic Editor: Sylvain Choquet

Copyright (c) 2020 Ricardo D. Parrondo et al. This is an open access article distributed under the Creative Commons Attribution License, which permits unrestricted use, distribution, and reproduction in any medium, provided the original work is properly cited.

\begin{abstract}
Extramedullary multiple myeloma is defined by the presence of plasma cell infiltration outside of the bone marrow. It is associated with a poor prognosis and resistance to therapy and is often associated with high-risk cytogenetics. Aggressive relapsed and refractory extramedullary multiple myeloma is often treated with salvage infusional chemotherapy to achieve rapid disease control. Commonly used regimens include DCEP, CVAD, and VTD-PACE. While VTD-PACE contains bortezomib and thalidomide which have potent antimyeloma activity, the advent of novel agent therapy with proteasome inhibitors and immunomodulatory agents being used in the first-line setting has resulted in many patients being refractory to bortezomib by the time they are treated with VTD-PACE. Herein, we discuss two cases of aggressive relapsed, high-risk, bortezomib-refractory extramedullary multiple myeloma treated with KRD-PACE and review the available clinical data on salvage chemotherapy regimens used in relapsed refractory myeloma.
\end{abstract}

\section{Introduction}

Multiple myeloma (MM) is a plasma cell neoplasm that accounts for $1 \%$ of all cancers and approximately $10 \%$ of all hematologic malignancies [1]. MM is defined by the presence of $\geq 10 \%$ of clonal plasma cells in the bone marrow (or a biopsy proven extramedullary plasmacytoma) and by endorgan damage attributable to the MM such as anemia, lytic bone lesions, renal failure, and hypercalcemia [1]. Approximately, $1 \%$ to $2 \%$ of patients have extramedullary disease (EMD) upon initial diagnosis and 8\% develop EMD later on in the disease course, typically after multiple relapses [2]. EMD is defined by the presence of soft-tissue plasmacytomas or plasma cell infiltration outside of the bone marrow [3]. The presence of high-risk cytogenetics (particularly del(17p) and amp [1q21]) is associated with development of EMD [4]. EMD is associated with an adverse prognosis in newly diagnosed and in relapsed MM patients and tends to be resistant to proteasome inhibitors, immunomodulatory agents, and even novel agents such as daratumumab [5-7]. As such, infusional "traditional" chemotherapy agents are used in the treatment of patients with relapsed/refractory $\mathrm{MM}$ (RRMM) as a means of rapid tumor debulking or as a bridge to high-dose therapy and stem cell transplant. Several such intensive infusional chemotherapy regimens are currently used.

In a population of patients with RRMM, hyperfractionated cyclophosphamide, vincristine, doxorubicin, and dexamethasone (CVAD) has been reported to produce an overall response rate (ORR) of $40 \%$ and a median overall survival (OS) of 15 months [8]. Dexamethasone with continuous-infusion cyclophosphamide, etoposide, and cisplatin (DCEP) demonstrated an ORR of $58 \%$ and a median response duration of 9 months in a population of RRMM 
patients [9]. In patients with RRMM, DT-PACE (thalidomide, dexamethasone, and 4-d continuous infusions of cisplatin, doxorubicin, cyclophosphamide, and etoposide) produced an ORR of $61 \%$ [10]. Bortezomib (V) is frequently administered with DT-PACE [11]. In RRMM, the proteasome inhibitor carfilzomib $(\mathrm{K})$ has proven to produce superior response rates, progression-free survival (PFS), and $\mathrm{OS}$ compared to $\mathrm{V}$ [12]. Likewise, the addition of $\mathrm{K}$ to lenalidomide $(\mathrm{R})$ and $\mathrm{D}$ produces superior response rates and PFS compared to RD in RRMM [13]. Furthermore, the overlapping toxicity of peripheral neuropathy by bortezomib and thalidomide makes them less desirable to combine in a regimen [14].

As a majority of patients may be heavily pretreated and refractory to $\mathrm{V}$ by the time they are considered for salvage infusional chemotherapy, we wanted to examine the efficacy of KRD-PACE as the salvage therapy for RRMM. Herein, we describe the efficacy and clinical course of two patients with aggressive, V-refractory, extramedullary, RRMM with highrisk cytogenetics who were treated with KRD-PACE and provide a succinct review of the literature.

\section{Discussion}

2.1. Patient 1. A 32-year-old male was diagnosed with a solitary plasmacytoma of the left $\mathrm{T} 4$ paraspinal area extending into the T4 vertebral body in the July of 2016. A CT-guided biopsy of the T4 lesion was performed which revealed sheets of kappa-restricted plasma cells. A bone marrow biopsy did not reveal a clonal plasma cell population. Serum protein electrophoresis revealed an $M$ spike of $0.7 \mathrm{~g} / \mathrm{dL}$, and immunofixation revealed an IgG kappa monoclonal protein. The patient subsequently received radiation therapy (RT) consisting of $360 \mathrm{cGy}$ in 2 fractions. Prior to receiving a $3^{\text {rd }}$ fraction of $\mathrm{RT}$, the patient developed acute onset severe back pain with bilateral lower extremity paresthesias and weakness. An MRI of the spinal canal revealed a persistent paraspinal mass and a new fracture of the T4 vertebrae. The patient subsequently underwent surgical resection of the plasmacytoma with reconstruction spinal fusion. Pathology revealed kappa-restricted plasma cells arising in sheets. The patient then underwent postoperative RT to the tumor bed receiving 3960 cGy in 22 fractions. In the May of 2018, the patient developed back pain, and an MRI of the back revealed a $5 \mathrm{~cm} \times 5.7 \mathrm{~cm}$ mass on the left T4 hemivertebra with extra vertebral extension along the posterior left chest wall. In the June of 2018, a biopsy of this lesion revealed kappa-restricted plasma cells in sheets. Fluorescence in situ hybridization (FISH) of the lesion revealed monosomies 1, 8, 13, 14, and 17, which includes loss of the TP53 gene region. Restaging workup is shown in Table 1 . The patient was not a candidate for additional RT or surgery to the spine, and thus was started on $\mathrm{V}$-cyclophosphamide-D (CyBorD) for relapsed, extramedullary multiple myeloma. After receiving one cycle of CyBorD, the patient continued to complain of back pain and developed worsening paresthesias of the thighs bilaterally and lower extremity weakness. An MRI of the thoracic spine revealed an increase in the size of the lateral aspect of the left- sided paraspinal mass with severe cord compression from T3 through T5, and 18F FDG PET-CT images are shown in Figure 1(a). Given the patient's poor response to CyBorD and urgency of cord compression, it was decided to start the patient on salvage carfilzomib (K), lenalidomide (R), dexamethasone (D), cisplatin (P), doxorubicin (A), cyclophosphamide (C), and etoposide (E); KRD-PACE. KRDPACE was dosed at $\mathrm{K}\left(20 \mathrm{mg} / \mathrm{m}^{2}\right.$ on days 1 and 2 followed by $56 \mathrm{mg} / \mathrm{m}^{2}$ on days $8,9,15$, and 16 ), $\mathrm{R}$ (25 mg daily on days $1-21)$, D (40 mg orally on days $1-4)$ with $\mathrm{P}\left(10 \mathrm{mg} / \mathrm{m}^{2} /\right.$ day $)$, A $\left(10 \mathrm{mg} / \mathrm{m}^{2} /\right.$ day $), \mathrm{C}\left(400 \mathrm{mg} / \mathrm{m}^{2} /\right.$ day $)$, and $\mathrm{E}\left(40 \mathrm{mg} / \mathrm{m}^{2} /\right.$ day) given as a continuous intravenous infusion over 24 hours on days 1-4 (Table 2 ). The patient tolerated two cycles of KRD-PACE well without the need for extended hospitalization, dose reductions, transfusion, or growth factor support. He did not develop febrile neutropenia. The patient had a very good partial response (VGPR) to therapy (Table 1) with near resolution of the paraspinal plasmacytoma (Figure 1(b)). He subsequently went on to stem cell mobilization and collection followed by a melphalan $200 \mathrm{mg} / \mathrm{m}^{2}$ salvage autologous stem cell transplant (ASCT) after which he obtained a complete response. $\mathrm{He}$ is currently on maintenance therapy with lenalidomide $10 \mathrm{mg}$ on days $1-21$ and ixazomib $2 \mathrm{mg}$ weekly, 13 months after KRD-PACE.

2.2. Patient 2. A 56-year-old male developed temporal-occipital headaches in the April of 2017. In the November of 2017, an MRI brain was done which revealed an enlarging enhancing skull base lesion involving the clivus, right temporal bone, right petrous apex, and bilateral occipital condyles with the involvement of the right hypoglossal canal. The MRI brain also picked up bilateral upper cervical lymphadenopathy. A subsequent skeletal survey revealed multiple poorly defined lytic lesions throughout the axial and appendicular skeleton. A CT of the chest, abdomen, and pelvis revealed left axillary, right retrocrural, and left pericardial lymphadenopathy. The patient had a multiple myeloma workup (Table 1) which revealed a high-risk, revised international scoring system (R-ISS) III IgA kappa myeloma. A biopsy of one of the aforementioned cervical lymph nodes revealed sheets of kappa-restricted plasma cells, and FISH revealed a duplication $1 \mathrm{q}$ consistent with extramedullary disease at diagnosis. Bone marrow cytogenetics revealed a $1 \mathrm{q}$ duplication as well as trisomy 6, 11, and 15 and monosomy 13. The patient was subsequently started on VRD in the December of 2017 and achieved a partial response after 4 cycles. The patient had progressive disease in the April of 2018 as evidenced by a pathologic right humerus midshaft fracture. He then had surgical fixation of the fracture (pathology revealed a plasmacytoma with kappa-restricted plasma cells) and was started on daratumumab (Dara)-R-D in the May of 2018. After 4 cycles of Dara-R-D, restaging labs and an 18F FDG PET-CT revealed stable disease. After 6 cycles of Dara-R-D, the patient developed disease progression manifested by back pain for which thoracic and lumbar CT scans revealed a pathologic fracture of L5 and multiple pathologic nondisplaced fractures of the rib cage. Extramedullary disease was noted on 18F FDG PET-CT 
TABLE 1: Response measurement and hematologic toxicity/recovery time after 2 cycles of KRD-PACE.

\begin{tabular}{|c|c|c|c|c|c|}
\hline \multicolumn{3}{|c|}{ Patient 1} & \multicolumn{3}{|c|}{ Patient 2} \\
\hline Parameter & $\begin{array}{l}\text { Staging studies at relapse } \\
\text { before KRD-PACE }\end{array}$ & $\begin{array}{l}\text { Staging studies } \\
\text { after } 2 \text { cycles of } \\
\text { KRD-PACE }\end{array}$ & Parameter & $\begin{array}{l}\text { Staging studies at relapse } \\
\text { before KRD-PACE }\end{array}$ & $\begin{array}{c}\text { Staging studies after } \\
2 \text { cycles of KRD- } \\
\text { PACE }\end{array}$ \\
\hline $\begin{array}{l}\text { ISS score (at } \\
\text { diagnosis) }\end{array}$ & I & - & $\begin{array}{l}\text { ISS score (at } \\
\text { diagnosis) }\end{array}$ & III & - \\
\hline $\begin{array}{l}\text { Revised-ISS score } \\
\text { (at diagnosis) }\end{array}$ & II & - & $\begin{array}{l}\text { Revised-ISS Score } \\
\text { (st diagnosis) }\end{array}$ & III & - \\
\hline Cytogenetics/ & Monosomies $1,8,13,14$ and & & Cytogenetics/ & 1q duplication. In & \\
\hline $\begin{array}{l}\text { FISH (at } \\
\text { diagnosis) }\end{array}$ & $\begin{array}{l}\text { 17, which includes loss of the } \\
\text { TP53 gene region }\end{array}$ & - & $\begin{array}{l}\text { FISH (at } \\
\text { diagnosis) }\end{array}$ & $\begin{array}{l}\text { addition, trisomy } 6,11 \text {, } \\
\text { and } 15, \text { monosomy } 13\end{array}$ & - \\
\hline $\mathrm{Hgb}$ & $14.2 \mathrm{~g} / \mathrm{dL}$ & $11.1 \mathrm{~g} / \mathrm{dL}$ & $\mathrm{Hgb}$ & $13.0 \mathrm{~g} / \mathrm{dL}$ & $11.1 \mathrm{~g} / \mathrm{dL}$ \\
\hline Plt & $172 \times 10^{9} / \mathrm{L}$ & 312 & Plt & $169 \times 10^{9} / \mathrm{L}$ & $68 \times 10^{9} / \mathrm{L}$ \\
\hline $\mathrm{Cr}$ & $0.86 \mathrm{mg} / \mathrm{dL}$ & $0.74 \mathrm{mg} / \mathrm{dL}$ & $\mathrm{Cr}$ & $0.96 \mathrm{mg} / \mathrm{dL}$ & $1.06 \mathrm{mg} / \mathrm{dL}$ \\
\hline $\mathrm{LDH}$ & $635 \mathrm{U} / \mathrm{L}$ & $184 \mathrm{U} / \mathrm{L}$ & LDH & $235 \mathrm{U} / \mathrm{L}$ & $159 \mathrm{U} / \mathrm{L}$ \\
\hline $\mathrm{B}_{2}$-microglobulin & $1.55 \mathrm{mcg} / \mathrm{mL}$ & $1.27 \mathrm{mcg} / \mathrm{mL}$ & $\mathrm{B}_{2}$-microglobulin & $9.41 \mathrm{mcg} / \mathrm{mL}$ & $2.37 \mathrm{mcg} / \mathrm{mL}$ \\
\hline M-spike & $0.9 \mathrm{~g} / \mathrm{dL}$ & $0.1 \mathrm{~g} / \mathrm{dL}$ & M-spike & $0.2 \mathrm{~g} / \mathrm{dL}$ & $0.1 \mathrm{~g} / \mathrm{dL}$ \\
\hline IFE & IgG kappa & IgG kappa & IFE & IgA kappa & $\begin{array}{l}\text { No monoclonal } \\
\text { protein }\end{array}$ \\
\hline IgG & $1410 \mathrm{mg} / \mathrm{dL}$ & $544 \mathrm{mg} / \mathrm{dL}$ & $\operatorname{IgG}$ & $257 \mathrm{mg} / \mathrm{dL}$ & $294 \mathrm{mg} / \mathrm{dL}$ \\
\hline $\operatorname{IgA}$ & $155 \mathrm{mg} / \mathrm{dL}$ & $92 \mathrm{mg} / \mathrm{dL}$ & $\operatorname{IgA}$ & $584 \mathrm{mg} / \mathrm{dL}$ & $9 \mathrm{mg} / \mathrm{dL}$ \\
\hline $\operatorname{IgM}$ & $80 \mathrm{md} / \mathrm{dL}$ & $24 \mathrm{mg} / \mathrm{dL}$ & $\operatorname{IgM}$ & $24 \mathrm{md} / \mathrm{dL}$ & $9 \mathrm{mg} / \mathrm{dL}$ \\
\hline Lambda & $0.738 \mathrm{mg} / \mathrm{dL}$ & $0.283 \mathrm{mg} / \mathrm{dL}$ & Lambda & $0.248 \mathrm{mg} / \mathrm{dL}$ & $0.042 \mathrm{mg} / \mathrm{dL}$ \\
\hline Kappa & $22.9 \mathrm{mg} / \mathrm{dL}$ & $0.701 \mathrm{mg} / \mathrm{dL}$ & Kappa & $1.25 \mathrm{mg} / \mathrm{dL}$ & $<0.030 \mathrm{mg} / \mathrm{dL}$ \\
\hline $\mathrm{K} / \mathrm{L}$ ratio & 31.02 & 2.48 & K/L Ratio & 5.04 & $<0.712$ \\
\hline $\begin{array}{l}\text { Bone marrow } \\
\text { biopsy }\end{array}$ & $\begin{array}{l}\text { 2-3\% kappa-restricted } \\
\text { atypical plasma cells. }\end{array}$ & - & $\begin{array}{l}\text { Bone marrow } \\
\text { biopsy }\end{array}$ & - & $\begin{array}{l}\text { No atypical plasma } \\
\text { cells detected. }\end{array}$ \\
\hline Response & - & $\begin{array}{l}\text { Very good partial } \\
\text { response }\end{array}$ & Response & - & Complete response \\
\hline $\begin{array}{l}\text { Plt nadir/time to } \\
\text { recovery }\end{array}$ & - & $69 \times 10^{9} / \mathrm{L} / 7$ days & $\begin{array}{l}\text { Plt nadir/time to } \\
\text { recovery }\end{array}$ & - & $8 \times 10^{9} / \mathrm{L} / 45$ days \\
\hline $\begin{array}{l}\text { ANC nadir/time } \\
\text { to recovery }\end{array}$ & - & $1.18 \times 10^{9} / \mathrm{L}$ & $\begin{array}{l}\text { ANC nadir/time } \\
\text { to recovery }\end{array}$ & - & $0.04 \times 10^{9} / 34$ days \\
\hline $\begin{array}{l}\mathrm{Hgb} \text { nadir/time to } \\
\text { recovery }\end{array}$ & - & $11.2 \mathrm{~g} / \mathrm{dL}$ & $\begin{array}{l}\mathrm{Hgb} \text { nadir/time to } \\
\text { recovery }\end{array}$ & - & $6.3 \mathrm{~g} / \mathrm{dl} / 48$ days \\
\hline
\end{tabular}

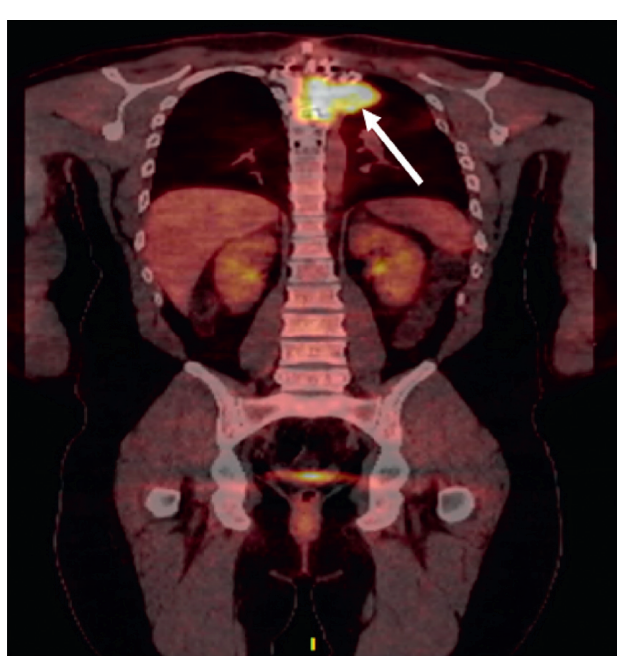

(a)

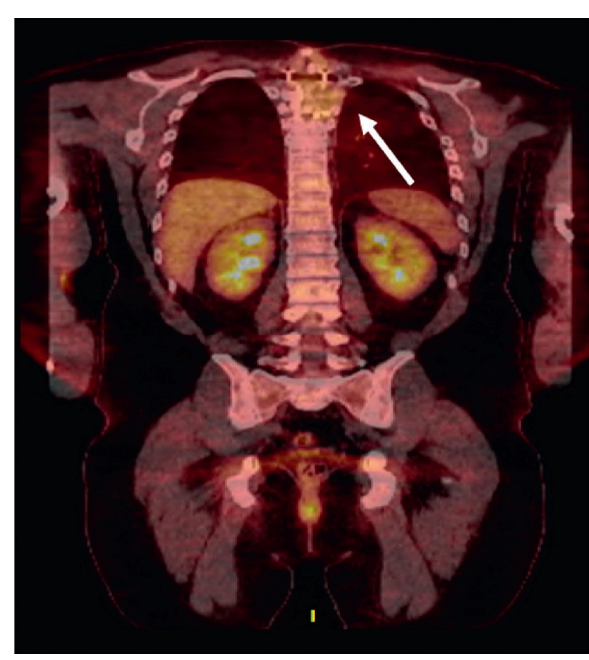

(b)

FIGURE 1: (a) 18F FDG PET-CT at relapse showing large soft-tissue mass replacing the T4 vertebral body (white arrow). (b) 18F FDG PETCT after 2 cycles of KRD-PACE showing near-complete resolution of the extraosseous soft-tissue component involving patient's known T4 vertebral body lesion (white arrow). 
TABLE 2: KRD-PACE dosing schedule for patient 1 and KRD-PACE dosing schedule for patient 2.

\begin{tabular}{|c|c|c|c|c|c|c|c|}
\hline 28d cycle & K & $\mathrm{R}$ & $\mathrm{D}$ & $\mathrm{P}$ & A & $\mathrm{C}$ & $\mathrm{E}$ \\
\hline $\begin{array}{l}\text { A: Patient } \\
\text { Dose } \\
\text { Schedule }\end{array}$ & $\begin{array}{l}\text { 1, KRD-PACE schedule } \\
20 \mathrm{mg} / \mathrm{m}^{2} \text { (day } 1 \text { ) then } 56 \mathrm{mg} / \mathrm{m}^{2} \text { thereafter } \\
\text { Days } 1,2,8,9,15,16\end{array}$ & $\begin{array}{c}25 \mathrm{mg} \\
\text { Days } 1-21\end{array}$ & $\begin{array}{c}40 \mathrm{mg} \\
\text { Days } 1-4\end{array}$ & $\begin{array}{l}10 \mathrm{mg} / \mathrm{m}^{2} \\
\text { Days } 1-4\end{array}$ & $\begin{array}{l}10 \mathrm{mg} / \mathrm{m}^{2} \\
\text { Days } 1-4\end{array}$ & $\begin{array}{c}400 \mathrm{mg} / \mathrm{m}^{2} \\
\text { Days } 1-4\end{array}$ & $\begin{array}{l}40 \mathrm{mg} / \mathrm{m}^{2} \\
\text { Days } 1-4\end{array}$ \\
\hline $\begin{array}{l}\text { B: Patient } \\
\text { Dose } \\
\text { Schedule }\end{array}$ & $\begin{array}{l}\text { 2, KRD-PACE schedule } \\
\left.20 \mathrm{mg} / \mathrm{m}^{2} \text { (day } 1\right) \text { then } 27 \mathrm{mg} / \mathrm{m}^{2} \\
\text { Days } 1,2\end{array}$ & $\begin{array}{c}15 \mathrm{mg} \\
\text { Days } 1-21\end{array}$ & $\begin{array}{c}40 \mathrm{mg} \\
\text { Days } 1-4\end{array}$ & $\begin{array}{l}10 \mathrm{mg} / \mathrm{m}^{2} \\
\text { Days } 1-4\end{array}$ & $\begin{array}{l}10 \mathrm{mg} / \mathrm{m}^{2} \\
\text { Days } 1-4\end{array}$ & $\begin{array}{c}400 \mathrm{mg} / \mathrm{m}^{2} \\
\text { Days } 1-4\end{array}$ & $\begin{array}{l}40 \mathrm{mg} / \mathrm{m}^{2} \\
\text { Days } 1-4\end{array}$ \\
\hline
\end{tabular}

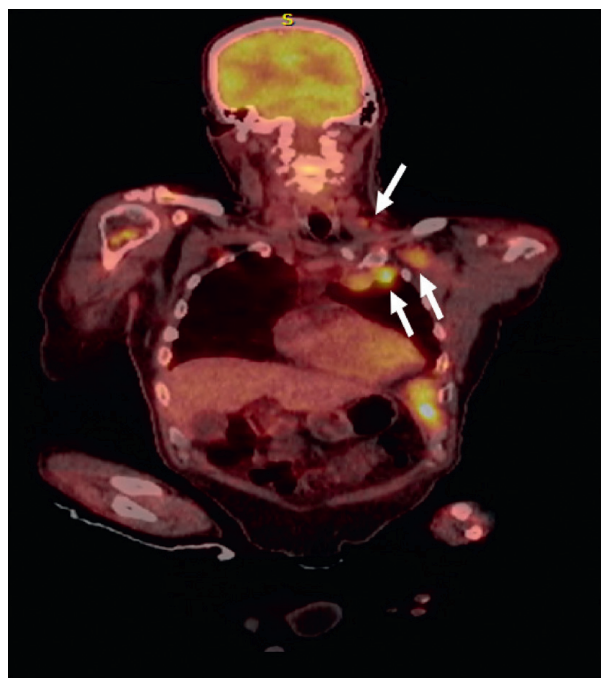

(a)

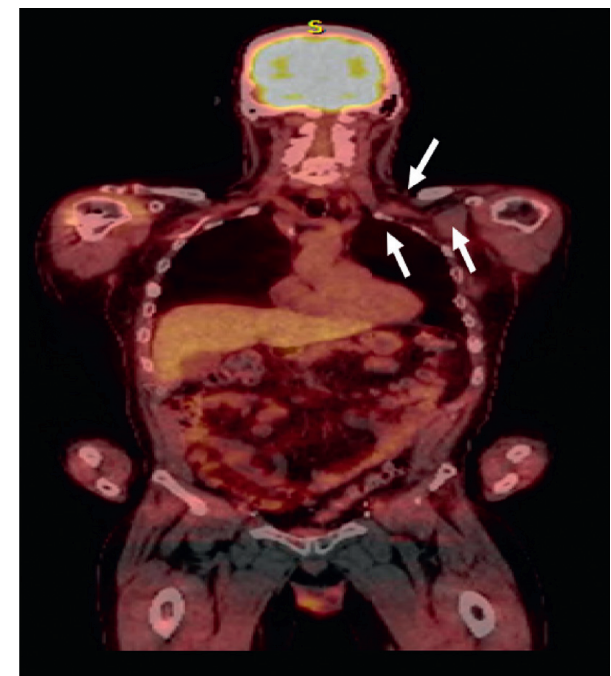

(b)

FIGURE 2: (a) 18F FDG PET-CT at relapse showing left cervical and supraclavicular adenopathy and numerous left subpectoral, axillary, and internal mammary adenopathy (white arrows). (b) 18F FDG PET-CT after 2 cycles of KRD-PACE revealing complete resolution of adenopathy.

(Figure 2(a)). Restaging studies are given in Table 1. Peripheral flow cytometry did not real evidence of plasma cell leukemia. The patient was subsequently started on KRDPACE salvage therapy with the following dosing schedule: $\mathrm{K}\left(20 \mathrm{mg} / \mathrm{m}^{2}\right.$ on day 1 followed by $27 \mathrm{mg} / \mathrm{m}^{2}$ on day 2 of each cycle), $\mathrm{R}$ (15 mg daily on days $1-21)$, D (40 mg orally on days $1-4)$ with $\mathrm{P}\left(10 \mathrm{mg} / \mathrm{m}^{2} /\right.$ day $), \mathrm{A}\left(10 \mathrm{mg} / \mathrm{m}^{2} /\right.$ day $), \mathrm{C}$ (400 $\mathrm{mg} / \mathrm{m}^{2} /$ day), and $\mathrm{E}\left(40 \mathrm{mg} / \mathrm{m}^{2} /\right.$ day $)$ given as a continuous intravenous infusion over 24 hours on days 1-4 (Table 2). He ultimately received 2 cycles of KRD-PACE. The patient developed grade 3 mucositis and anemia, grade 4 thrombocytopenia and neutropenia requiring transfusion (a total of 8 units of packed red cells and 10 units of platelets), and growth factor support (three $6 \mathrm{mg}$ filgrastim injections), as well as a right upper extremity deep venous thrombosis (Table 1). He did not develop neutropenic fever. The patient was only hospitalized for 4 days during each cycle of KRD-PACE and was never rehospitalized. Transfusional and growth factor support was managed in the outpatient setting. The patient had a complete response (CR) to therapy (Table 1) with a resolution of lymphadenopathy (Figure 2(b)). He went on to stem cell mobilization but was unable to collect an adequate number of stem cells on two occasions. He remained in CR of therapy but developed an extramedullary relapse 6 months after completion of KRD-PACE and is now being considered for enrollment in an anti-B-cell maturation antigen (BCMA) chimeric antigen receptor $\mathrm{T}$-cell (CAR-T) therapy trial.

\section{Conclusion}

We describe two cases of aggressive, relapsed, bortezomibrefractory extramedullary MM with high-risk cytogenetics who achieved deep responses with KRD-PACE salvage therapy. One of the patients, a 32-year-old male with minimal MM bone marrow involvement and less prior treatment, tolerated 2 cycles of KRD-PACE without any complications or need for transfusional support. He achieved a VGPR and proceeded to high-dose therapy and ASCT to which he achieved a CR. The 56-year-old patient had extensive bone marrow involvement and 2 prior lines of treatment. He tolerated 2 cycles of KRD-PACE without the need for extended hospitalization, but developed profound cytopenias which required 34-48 days to recover and multiple red cell and platelet transfusions as well as granulocyte colony stimulating factor support. He achieved a complete response which lasted for 6 months without additional therapy. 
DCEP, CVAD, and VTD-PACE-like regimens are the most commonly used infusional salvage chemotherapy regimens in patients with RRMM. In a retrospective analysis of 107 patients with RRMM, the ORR, PFS, and OS were 52\%, 3.8 months, and 8.9 months for DCEP; $49 \%, 5.8$ months, and 8.3 months for CVAD; and 73\%, 4.5 months, and 8.5 months for VTD-PACE, respectively [15]. There were no significant differences in response rates or survival benefit amongst the three regimens [15]. Patients received a median number of 2 cycles, $>70 \%$ were refractory to $\mathrm{V}$ and $>60 \%$ were refractory to $\mathrm{R}$ [15]. Successful autologous transplant after salvage chemotherapy was associated with superior PFS (HR, 0.25; 95\% CI, 0.14-0.45) and OS (HR 0.19, 95\% CI, 0.12-0.30) [15]. High-risk cytogenetics $(P=0.05)$ and $\operatorname{EMD}(P=0.006)$ were the factors associated with inferior OS in the study population [14]. Common adverse effects were increased transfusion requirements $(62 \%)$, febrile neutropenia (37\%), delays in treatment $(36 \%)$, rehospitalization $(34 \%)$, venous thromboembolism (6\%), dose reductions due to adverse events (5\%), and treatment-related mortality (7\%) [15]. There was a trend toward more febrile neutropenia with VTD-PACE and prolonged hospitalization among patients treated with CVAD, but there were no statistically significant differences in adverse events among the 3 regimens [15]. In a retrospective study of 141 patients with RRMM treated with VTD-PACElike regimens, ORR was 54\%, OS was 8.1 months, and PFS was 3.1 months [16]. Most patients received 1-2 cycles of a VTDPACE-like regimen, $85 \%$ were refractory to $\mathrm{V}$, and $60 \%$ were refractory to R. Patients required a median of 4 packed red cell transfusions and 4 platelet transfusions during cycle 1 [16]. Median time to recovery of absolute neutrophil count and platelet count from initiation of a VTD-PACE-like regimen was 18 (range, 12-44) and 21(range 11-45) days, respectively [16]. Age $\geq 60$ (HR 2.28, 95\% CI, 1.41-3.70) and R-ISS III (HR 2.38, 95\% CI, 1.35-4.04) predicted shortened OS [16]. Presence of EMD and high-risk cytogenetics, and being refractory to proteasome inhibitors or immunomodulatory agents were not associated with shortened OS [16].

Salvage chemotherapy regimens, including the most intensive regimen, VTD-PACE, confer a median OS of 8 months and a median PFS of 3-4 months for RRMM patients based on the current published studies $[15,16]$. OS and PFS are even shorter for patients with high-risk cytogenetics and EMD. Given that over $60 \%$ of patients in the aforementioned studies were refractory to $\mathrm{V}$ and $\mathrm{R}$ when they received salvage regimens, substitution of VT for KR to make KRD-PACE is a plausible alternative. A study by Cowan et al. examined the use of KRD-PACE for chemomobilization in 20 patients with RRMM [17]. 15 patients received 1 cycle of KRD-PACE, and 5 patients received 2 cycles. The ORR was $25 \%$ with $75 \%$ achieving stable disease. $100 \%$ of patients underwent ASCT. No patients experienced cardiac toxicity. Following transplant, the median time to neutrophil engraftment was 18 days and the median time to platelet engraftment was 13 days. The PFS at 6 months was 63\% (95\% CI, 0.382-1), and the OS at 6 months was 91\% (95\% CI, 0.754-1) [17]. Harrell et al. reported a retrospective study of 52 patients with RRMM who were treated with KD-PACE-like regimens [18]. In this study, 54\% of patients had high-risk cytogenetics and had received a median of 3 prior lines of therapy and $64 \%$ had KD-PACE together with an immunomodulatory agent. Grade 3/4 toxicities included neutropenia (93\%), thrombocytopenia (87\%), and anemia $(37 \%)$. Febrile neutropenia occurred in $35 \%$. The overall response rate $(\geq \mathrm{PR})$ was $77 \%$ including $\mathrm{CR}(12 \%)$, VGPR (23\%), and PR (42\%). Median PFS was 4.6 mo (95\% CI 3.2-7.5 mo) and median OS $11.2 \mathrm{mo}$ (95\% CI $6.1-14.5 \mathrm{mo}$ ) [18].

Relapsed refractory extramedullary MM with high-risk cytogenetics is a highly aggressive, treatment-refractory disease state with a dismal prognosis. Salvage chemotherapy followed by ASCT is one of the few treatment options that can prolong survival and act as a bridge to a clinical trial. While most patients are refractory to $\mathrm{V}$ by the time they are treated with salvage regimens, KRD-PACE offers an efficacious option for treatment that introduces a novel agent (K) highly active in RRMM. In the ASPIRE and ENDEAVOR trials, $\mathrm{K}$ has proven to produce superior ORR, OS, and PFS compared to $\mathrm{V}$-based or R-based regimens in RRMM [12,13]. Furthermore, in the ASPIRE trial, KRD was superior to RD for PFS across high-risk cytogenetic risk groups, suggesting that this combination partly abrogates the negative impact of $t(4 ; 14)$ and $\operatorname{del}(17 \mathrm{p})$ [13]. Prospective trials evaluating the safety and efficacy of salvage KRDPACE in RRMM, especially patients with high-risk myeloma and those with EMD, are warranted.

\section{Conflicts of Interest}

The authors declare that they have no conflicts of interest.

\section{References}

[1] S. V. Rajkumar, M. A. Dimopoulos, A. Palumbo et al., "International myeloma working group updated criteria for the diagnosis of multiple myeloma," The Lancet Oncology, vol. 15, no. 12, pp. e538-e548, 2014.

[2] K. D. Short, S. V. Rajkumar, D. Larson et al., "Incidence of extramedullary disease in patients with multiple myeloma in the era of novel therapy, and the activity of pomalidomide on extramedullary myeloma," Leukemia, vol. 25, no. 6, pp. 906-908, 2011.

[3] M. Weinstock and I. M. Ghobrial, "Extramedullary multiple myeloma," Leukemia \& Lymphoma, vol. 54, no. 6, pp. 1135-1141, 2013.

[4] X. Qu, L. Chen, H. Qui et al., "Extramedullary manifestation in multiple myeloma bears high incidence of poor cytogenetic aberration and novel agents resistance," BioMed Research International, vol. 2015, Article ID 787809, 7 pages, 2015.

[5] N. Gagelmann, D.-J. Eikema, S. Iacobelli et al., "Impact of extramedullary disease in patients with newly diagnosed multiple myeloma undergoing autologous stem cell transplantation: a study from the chronic malignancies working party of the EBMT," Haematologica, vol. 103, no. 5, pp. 890-897, 2018.

[6] S. Z. Usmani, C. Heuck, A. Mitchell et al., "Extramedullary disease portends poor prognosis in multiple myeloma and is over-represented in high-risk disease even in the era of novel agents," Haematologica, vol. 97, no. 11, pp. 1761-1767, 2012. 
[7] M. Pick, V. Vainstein, N. Goldschmidt et al., "Daratumumab resistance is frequent in advanced-stage multiple myeloma patients irrespective of CD38 expression and is related to dismal prognosis," European Journal of Haematology, vol. 100, no. 5, pp. 494-501, 2018.

[8] M. A. Dimopoulos, D. Weber, H. Kantarjian, K. B. Delasalle, and R. Alexanian, "HyperCVAD for VAD-resistant multiple myeloma," American Journal of Hematology, vol. 52, no. 2, pp. 77-81, 1996.

[9] M. Dadacaridou, X. Papanicolaou, D. Maltesas et al., "Dexamethasone, cyclophosphamide, etoposide and cisplatin (DCEP) for relapsed or refractory multiple myeloma patients," Journal of Balkan Union of Oncology, vol. 12, no. 1, pp. 41-44, 2007.

[10] B. Barlogie, E. Anaissie, F. van Rhee et al., "Incorporating bortezomib into upfront treatment for multiple myeloma: early results of total therapy 3," British Journal of Haematology, vol. 138, no. 2, pp. 176-185, 2007.

[11] C.-K. Lee, B. Barlogie, N. Munshi et al., "DTPACE: an effective, novel combination chemotherapy with thalidomide for previously treated patients with myeloma," Journal of Clinical Oncology, vol. 21, no. 14, pp. 2732-2739, 2003.

[12] M. A. Dimopoulous, P. Moreau, A. Palumbo et al., "Carfilzomib and dexamethasone versus bortezomib and dexamethasone for patients with relapsed or refractory multiple myeloma (ENDEAVOR): a randomised, phase 3, open-label, multicentre study," The Lancet Oncology, vol. 17, no. 1, pp. 27-38, 2016.

[13] A. K. Stewart, S. V. Rajkumar, M. A. Dimopoulos et al., "Carfilzomib, lenalidomide, and dexamethasone for relapsed multiple myeloma," New England Journal of Medicine, vol. 372, no. 2, pp. 142-152, 2015.

[14] M. Pineda-Roman, M. Zangari, F. van Rhee et al., "VTD combination therapy with bortezomib-thalidomide-dexamethasone is highly effective in advanced and refractory multiple myeloma," Leukemia, vol. 22, no. 7, pp. 1419-1427, 2008.

[15] P. T. Griffin, V. Q. Ho, W. Fulp et al., "A comparison of salvage infusional chemotherapy regimens for recurrent/refractory multiple myeloma," Cancer, vol. 121, no. 20, pp. 3622-3630, 2015.

[16] A. Lakshman, P. P. Singh, S. V. Rajkumar et al., "Efficacy of VDT PACE-like regimens in treatment of relapsed/refractory multiple myeloma," American Journal of Hematology, vol. 93, no. 2, pp. 179-186, 2018.

[17] A. J. Cowan, M. Karami, E. N. Libby et al., "Outcome of multiple myeloma patients treated with carrd-PACE chemomobilization: a single-center experience," Blood, vol. 128, no. 22, p. 3377, 2016.

[18] S. Harrell, M. Khan, B. Dhakal, H. Parameswaran, and R. Cornell, "KD-PACE salvage therapy for aggressive relapsed multiple myeloma," Clinical Lymphoma Myeloma and Leukemia, vol. 19, no. 10, pp. e252-e253, 2019. 